The government of life

Managing populations, health and scarcity

Villadsen, Kaspar; Wahlberg, Ayo

Published in:

Economy and Society

DOI:

10.1080/03085147.2014.983831

Publication date:

2015

Document version

Peer reviewed version

Citation for published version (APA):

Villadsen, K., \& Wahlberg, A. (2015). The government of life: Managing populations, health and scarcity. Economy and Society, 44(1), 1-17. https://doi.org/10.1080/03085147.2014.983831 
This paper has been accepted for publication in Economy \& Society, and the final (edited, revised and typeset) version of this paper will be published in Economy \& Society, Volume 43, by Taylor \& Francis, All rights reserved. (C) Taylor \& Francis Group

\title{
The Government of Life:
}

\section{Managing populations, health, and scarcity}

\author{
Kaspar Villadsen and Ayo Wahlberg
}

In the present context, a number of transformations are taking place within the broad domain which one might term 'the government of life'. By government of life we refer to assemblages of knowledges and practices which regulate, administer, optimise and strengthen the vital characteristics of man-as-livingbeing. Central to the streams of research attempting to address these transformations has been the heritage of Michel Foucault, in particular his concepts of biopolitics and governmentality. In the past few decades, considerable conceptual work has been carried out around these notions, initially proposed by Foucault in his analyses of the emergence of modern power/knowledge configurations in $18^{\text {th }}$ and $19^{\text {th }}$ century Western Europe (Foucault, 1990; 2003; 2008). Although the two concepts were contemporaneous in these initial analyses, further conceptual development has tended to be rather disconnected. Very schematically speaking, research into the government of life has divided into three major threads each of which today revolves around distinct debates and intellectual development.

\section{Governmentalization, molecular politics, and sovereign power}

First, a particular style of scholarship coalesced around empirical analyses of political power in terms of a problematics of government rather than as a problem of the State. Focusing on the ways in which historically contingent forms of 'the conduct of conduct' emerged out of interlinked political rationalities/mentalities and technologies/techniques of government, this body of work has demonstrated the analytical traction that can be gained from mapping out how particular modes of problematisation

Kaspar Villadsen, Department of Management, Politics, Philosophy, Copenhagen Business School, Porcelanshaven 18B, Frederiksberg, 2000, Denmark (Corresponding address). Email: kv.mpp@cbs.dk Ayo Wahlberg, Department of Anthropology, University of Copenhagen, Øster Farimagsgade 5, 1353 Copenhagen, Denmark, Email: ayo.wahlberg@anthro.ku.dk 
This paper has been accepted for publication in Economy \& Society, and the final (edited, revised and typeset) version of this paper will be published in Economy \& Society, Volume 43, by Taylor \& Francis, All rights reserved. (C) Taylor \& Francis Group

rely on and generate regimes of truth and practice, knowledge and power (Dean, 1999; Barry, Osborne, \& Rose, 1996; Rose \& Miller, 1992; Bröckling, Krasmann, \& Lemke, 2010). These 'governmentality studies' have revolved around questions of the government of living humans, typically taking an empirical point of departure in, for instance, alcoholism (Valverde, 1997), psychosomatic illness (Greco, 1993), lifestyle diseases (Piii \& Villadsen, 2013), pregnancy (Weir, 2006), smoking (Larsen, 2010) or herbal medicine (Wahlberg, 2006). In this strand, a central question has been how to intervene to secure the health of individuals who are 'made up' as subjects of free will-power and autonomy. Hence, the establishing of practices, programs and technologies purporting to create self-responsible health subjects have received particular attention in this research. Novel contributions are still emerging from within this governmentality tradition but it seems to have had its peak in the 1990s, particularly in the Englishspeaking academic community. It has been argued that a certain redundancy and loss of critical impact has struck governmentality studies insofar as key assumptions herein become increasingly commonplace and incorporated into political and administrative health initiatives (Greco, 2009: 13; Dean, 2002; Villadsen \& Karlsen, 2012).

Second, social science scholars have taken up the conceptual and empirical challenge to examine the more tangible ways in which 'life itself' became the object of a bio-politics which has brought biological life and its mechanisms into realms of explicit calculation and intervention. This body of work has focused on how advanced biological sciences (genomics, neuroscience, reproductive science and other life sciences) are transforming the ways in which life comes to be made knowable, calculable and perhaps controllable at cellular and molecular levels (Rabinow, 1996; Franklin, 2000; Rabinow \& Rose, 2006; Rose, 2007; Rajan, 2006). These recent studies have made much of the 'molecular turn' in advanced biological sciences suggesting that bio-power today is in important ways playing out in a molecular realm of DNA, cells, tissues and synapses. Indeed, Sarah Franklin, in reflecting on Ian 
This paper has been accepted for publication in Economy \& Society, and the final (edited, revised and typeset) version of this paper will be published in Economy \& Society, Volume 43, by Taylor \& Francis, All rights reserved. (C) Taylor \& Francis Group

Wilmut's suggestion that 'Dolly the sheep has taken us into the age of biological control', argues that 'a shift has occurred from the idea of the biological as subject to conditions, which can be deciphered and understood, to a view of biology as entirely unconditional, and thus subject only to the limits imposed upon it from outside' (Franklin, 2007, p. 33). Notwithstanding the important insights that continue to emerge from this body of scholarship, we suggest that analytical conceptualisations of life as biological regulation of cells, synapses and genes should be supplemented with an attentiveness towards other equally pertinent (to the 21 st century) understandings of man-as-living-being. There is more to biopolitics than molecular biology.

And finally, another group of scholars has found inspiration in Foucault's concept of biopolitics to explore themes pertinent to political philosophy. Here, one may situate Giorgio Agamben's (1998) argument that the notion of sovereignty as power over 'life' is among the conditions of emergence of Western political thought. Similarly, Michael Hardt and Antonio Negri (2000) invoked the notion of biopolitics in their attempt to conceptualize an over-arching post-modern regime of globalized capitalism within which the material production of commodities has become inseparable from the reproduction of life and identities. And Roberto Esposito (2008) discussed what he takes to be a contemporary biopolitics of mastery and negation of life and sought to pave the way for a conceptualization of a positive politics of life and vitality. Among these political-philosophical contributions we also place Slavoj Zizek (2004) and Alain Badiou (2007) who also situate their interrogation of biopolitics along grand lines - the history of Western political thought and the major ideological projects of European modernity. Common to this stream of work is reference to the deadly dimension of biopolitics emblematically manifested in euthanasia, ethnic and religious persecution, the biopolitics of extreme political regimes, and 'the camp' as the paradigmatic place of biopower. In this body of work, biopolitics is inextricably bound to what Foucault was inclined to call a 'thanatopolitics', a politics of death. 
This paper has been accepted for publication in Economy \& Society, and the final (edited, revised and typeset) version of this paper will be published in Economy \& Society, Volume 43, by Taylor \& Francis, All rights reserved. (C) Taylor \& Francis Group

In this special feature section of Economy \& Society, we propose to bring these strands of conceptual innovation together through a prism of the 'government of life' with a particular focus on the population as one of the foremost sites within which efforts to regulate, administer and optimise life continue to unfold today. Yet, importantly, we wish to pay attention to the practical and persistent problems of governing, in contrast to the dramatic and 'exceptional' cases of biopolitics often foregrounded within the political philosophy thread, albeit now significantly repositioned in Agamben's recent work (2011; Bussolini, 2010; Dean, 2012). We also wish to sustain the explicit emphasis on political problems of governing which have received relatively less attention in the stream of biopolitical studies focused on biomedical and molecular advances in the life sciences. We maintain that efforts to govern life today are not restricted to targeting people's biological existence in a narrow sense, as if only distinct biological and medical problems can appear under the gaze of biopolitics. Rather, modern biopolitics concerns itself with the biological life of man as it is lived out within small or big scale environments, covering an almost limitless number of actors that may be perceived as influential upon living humans. The distinction between biological life and living as an activity, practiced in multifarious ways (whether social, economic or cultural) is crucial and the following articles will in different ways explore the configurations of interplay between them.

Of course, in its general definition, biopolitics was used to mark the moment at which man as a living being emerges at the centre of political calculation in a particular aggregated form (Foucault, 1990, p. 143). Biopolitics, Foucault argued, is 'addressed to a multiplicity of men, not to the extent that they are nothing more than their individual bodies, but to the extent that they form, on the contrary, a global mass that is affected by overall processes characteristic of birth, death, production, illness, and so on' (2003, p. 242). Accordingly, 'the population' emerged as the key object of knowledge production and political intervention. Indeed, it was at this same moment that governmentality emerged as an 'ensemble 
This paper has been accepted for publication in Economy \& Society, and the final (edited, revised and typeset) version of this paper will be published in Economy \& Society, Volume 43, by Taylor \& Francis, All rights reserved. (C) Taylor \& Francis Group

formed by the institutions, procedures, analyses and reflections, the calculations and tactics that allow the exercise of this very specific albeit complex form of power' that took the population as its main object (Foucault, 2007, p. 108).

Yet, in suggesting an analytical refocusing towards the government of life we argue that comparatively little attention has been directed towards the population as a natural-cultural entity in itself. The interweaving of biological and economic knowledge was common to the ways in which the population was conceptualised in the $18^{\text {th }}$ and $19^{\text {th }}$ centuries where terms like 'natural laws', 'the natural cause of things', 'the naturalness of society' were frequent. Foucault spoke in terms of the "natural-cultural reality" of the population and demonstrated how liberal thinkers like Adam Ferguson conceived of the population, or in this context civil society, as a self-generating natural and cultural order (2008, p. 298314). This dual conception of the object of biopolitics has not been sufficiently explored in hitherto research focussing on biopolitics and governmentality. We submit, however, that a lot can be gained from approaching bio-politics as a vital politics that is much broader in scope than the bio-prefix might suggest. Wherever there is life there is living and for this reason, a population will always be at once natural and cultural; knowledge of life (in Canguilhem's life science sense (2004)) should not be analytically privileged over the kinds of knowledge of living that have emerged out of the social and human sciences. As such, the government of life does not only address 'life itself', but rather addresses man-as-living being which points us to all the different ways in which human life is sustained, lived, organised, mobilised, experienced, optimised and more. The 'population' as a multiplicity of men is certainly, as we have pointed out, conceived of in the aggregated biological terms of birth, sickness and death rates, yet this aggregated multiplicity is also conceived of as comprising a 'society', a 'civil society', a 'culture', an 'economy', a 'polity' or a 'community'. It is with this interplay between knowledge of life and knowledge of living in contemporary efforts to manage populations that contributors to this special feature engage. In the following we outline four dimensions of bio-politics 
This paper has been accepted for publication in Economy \& Society, and the final (edited, revised and typeset) version of this paper will be published in Economy \& Society, Volume 43, by Taylor \& Francis, All rights reserved. (C) Taylor \& Francis Group

and related forms of governing which we suggest will be helpful for an analytics of the government of life today: vital threats, seriality, normalization and freedom.

\section{Vital threats, death power and scarcity}

The first analyses of modern biopolitics of the population appear in History of Sexuality 1 (Foucault, 1990) and in Society Must Defended (Foucault, 2003). When employed in these contemporaneous contexts, Foucault foregrounds 'state-racism' and the theme of death power associated with the quest for strengthening, sanitizing and securing living populations. A corollary to this quest were attempts to identify and cleanse out elements allegedly threatening the population from its inside, an internal purification. On this account, 'state-racism' is an urge innate to the modern state-project, 'a racism that society will direct against itself, against its own elements, and its own products' (2003, p. 62). It is the rearticulation of sovereign power which has as its essential operation the right to seizure, the right to life and death, that is, letting live and taking life, that connects it to the extreme political regimes of the $20^{\text {th }}$ century which established advanced apparatuses of calculation, knowledge and techniques for the control of human life in tandem with political structures underpinned by an ultimately totalitarian ideology. In such regimes, the intensification of the force of the population is typically paralleled by persecution or eugenics of political dissidents or individuals deemed racially or ethnically inferior. However, the state-racist variant of biopolitics is not the exclusive property of authoritarian and extreme political regimes like Stalinism, National Socialism, or Fascism. On the contrary, a deep-seated impetus to improve and purify life remains as innate potential in modern (liberal) political rationality in its most broad definition (Foucault 1982, p. 209).

Although ethnic cleansing, persecutions or the slaughtering of millions of people on an industrial scale can be carried out in the name of protecting the population, these acts are not the logical consequence of bio-politics, since they contradict the imperative of fostering life. Killings or massacres carried out on a 
This paper has been accepted for publication in Economy \& Society, and the final (edited, revised and typeset) version of this paper will be published in Economy \& Society, Volume 43, by Taylor \& Francis, All rights reserved. (C) Taylor \& Francis Group

state's own population follow from the sovereign's unquestionable right to take life: 'They follow from the logic of sovereign power, which legitimates killing by whatever arguments it chooses, be it God, Nature, or life' (Ojakangas, 2005, p 21). Today, in the context of Western liberal democracies, it is certainly the latter category of life which appears as the final reference point in political justifications for exercising sovereign death power. Recent articulations by state authorities of 'security threats' that require exceedingly extreme police and military interventions typically revolve around arguments for ensuring the vital dynamics of living populations.

Addressing issues of sovereign power over life and internal threats to a population, Mitchell Dean connects to this first version of biopolitics, while emphasizing the latter's neglect of the Malthus Effect that reached a certain apogee while he was discussing these matters. As he shows in his article in this issue, internal threats to the population do not only take the form of a biologically underpinned racism, rather they also take the form of excessive vital activity. Dean explores Thomas Malthus' thesis on population growth, scarcity and appropriate state policy as paradigmatic of a certain enduring strand of contemporary, liberal government. With the 'Malthusian moment', 'overpopulation' became the problem through which issues of global poverty and economic development, and concerns as different as national security and immigration began to be viewed. Vital threats to the population, in this sense, were generated through the aggregated results arising from the excesses of social life, particularly the human race's innate proclivity to procreate.

\section{A topology of governmental rationalities}

The second dimension of biopolitics foregrounds 'the population' as a non-unified, complex and indeterminate object of government. It displays how issues of governing and securing the population are stretched out between diverse, and contradictory governmental rationalities, including juridical sovereignty, discipline, and security. Biopolitics, as initially conceived, operated at the level of the 
This paper has been accepted for publication in Economy \& Society, and the final (edited, revised and typeset) version of this paper will be published in Economy \& Society, Volume 43, by Taylor \& Francis, All rights reserved. (C) Taylor \& Francis Group

population and hence was complementary to already existing disciplinary practices and institutions which targeted the human body. There would henceforth be two major poles of power, ranging from discipline which targeted 'the individual body' to 'biopolitics' which took as its object 'a multiplicity of men' (Foucault, 2003, p. 242). These formulations on issues pertinent to the management of the population left ample space for indeterminacy and dynamic repercussions between divergent rationalities. Collier observes that in the late 1970s, Foucault departed from his analysis of 'disciplinary society' and its diagnostic style marked by systematicity, functional coherence and a totalizing reach and instead began pursuing a 'topological' approach that led to much more subtle descriptions of multiple and heterogeneous configurations of power (Collier, 2009, p. 79-80). Problems inherent to a living population like crime, fluctuating grain production and the control of epidemics begin to oscillate between different governmental rationalities and thus become something entirely different depending on the specific optical frame and calculative rationality. Different governmental rationalities may target the same problem, for instance, a specific crime, from within each of their limited optics, ascribing to it fundamentally divergent meanings, causes, and effects. Rather than a unified totality, the population begins to emerge as a rather indeterminate set of forces which unfolds itself over time in an infinite seriality.

The key site for the emergence of issues of population management in the $17^{\text {th }}$ and $18^{\text {th }}$ centuries was the city. It was within the city that epidemics, hygiene, and sexuality became urgent matters bearing upon the vitality of the population. The city appeared as an indeterminate or 'overdetermined' site of governmental intervention organised around three major technologies of power or 'prototypes': 'law', 'discipline' and 'security' (Foucault, 2007, p. 5-24). On the basis of 17th and 18th century texts about town planning, Foucault showed how these technologies produce particular problems and solutions regarding population issues from within their own distinct rationality. Schematically, the principal object of legal sovereignty is the territory, discipline targets human bodies, and security concerns the 
This paper has been accepted for publication in Economy \& Society, and the final (edited, revised and typeset) version of this paper will be published in Economy \& Society, Volume 43, by Taylor \& Francis, All rights reserved. (C) Taylor \& Francis Group

totality of a living population (2003: 253; 2007, p. 11). The legal technology effectuates 'a binary division between the permitted and the prohibited, and a coupling, comprising the code, between a type of prohibited action and a type of punishment' (2007, p. 5). Within the framework of discipline 'a series of adjacent, detective, medical, and psychological techniques appear which fall within the domain of surveillance, diagnosis, and the possible transformation of individuals' (2007, p. 5). And finally, the technology of security 'establishes an average considered as optimal on the one hand, and, on the other, a bandwidth of the acceptable that must not be exceeded' (2007, P. 6). Hence, fundamentally different objects possessing particular inherent mechanisms are rendered calculable by the three major rationalities that 'over-determine' the city as a site of regulation.

Security appears as the principal, modern rationality for reflecting upon issues of managing a living population. Security calculations take as their point of departure 'the naturalness of society', which is a composite of the natural and the cultural, i.e., the regularities by which populations produce, consume, procreate, move, organise, etc. In contrast to discipline, security mechanisms include 'forecasts, statistical estimates, and overall measures... [and] their purpose is not to modify any given phenomenon as such or to modify a given individual insofar as he is an individual, but, essentially, to intervene at the level at which these general phenomena are determined, to intervene at the level of the generality' (Foucault, 2003, p. 246). It is a rationality which recognizes that human reality is not amenable to planning and regulation that would completely eliminate the undesired. Rather, security has the more limited ambition of facilitating and optimizing the processes already inherent in this reality. Thus, security starts from the given: 'This given will not be reconstructed to arrive at a point of perfection, as in a disciplinary town. It is simply a matter of maximizing the positive elements, for which one provides the best possible circulation, and of minimizing what is risky and inconvenient, like theft and disease, while knowing that they will never be completely suppressed' (Foucault, 2007, p. 19). It follows that technologies of security depend more radically upon the objects of regulation than the two other 
This paper has been accepted for publication in Economy \& Society, and the final (edited, revised and typeset) version of this paper will be published in Economy \& Society, Volume 43, by Taylor \& Francis, All rights reserved. (C) Taylor \& Francis Group

prototypes. One key reason for this is that it operates with the population as both 'object and subject' of security mechanisms (Foucault, 2007, p. 11).

Within this framework of security, the problem of limits to government became a core political concern when governmental intervention was linked to the idea that individuals inhabit 'milieus' in which series of elements and exchanges unfold. Security is precisely a governmental rationality which seeks to take the open-ended unfolding of such series into account. It works through 'series of probabilities' (2007, p. 19) in so far as it seeks to prepare for the future and account for future possibilities. Instead of the prince's territory articulated as providential world order, political power would be faced with an open horizon of indefinite worldly events. Modern government would increasingly be about securing and optimizing these series: 'In short, I think we can speak here of a technique that is basically organized by reference to the problem of security, that is to say, at bottom, to the problem of the series. An indefinite series of mobile elements' (Foucault, 2007, p. 35). The population constitutes a spatial-temporal zone of open series that would be beyond the reach of sovereign command.

What it means to 'securitize' series of events in contrast to regulating them by law or discipline is explored in Andrew Lakoff's article which traces a significant transformation within attempts to determine whether a potentially catastrophic outbreak in a population is imminent. 'If disciplinary mechanisms seek to restrict the circulation of disease, isolating the sick from the healthy (as in quarantine)' he writes, 'security mechanisms allow disease to circulate but minimize its damage through collective interventions such as mass vaccination' (Lakoff, in this issue). Examining the response of the World Health Organisation (WHO) to the H1N1 or 'bird flu' outbreak in 2009, Lakoff argues that a new form of global pandemic preparedness has coalesced around efforts to catch 'early warning' signals allowing for 'real time' adjustment of policy and practice as an event unfolds. If 'actuarial devices' have used historical data on patterns of incidence of events in order to make rational calculations about future 
This paper has been accepted for publication in Economy \& Society, and the final (edited, revised and typeset) version of this paper will be published in Economy \& Society, Volume 43, by Taylor \& Francis, All rights reserved. (C) Taylor \& Francis Group

probabilities, he suggests newer 'sentinel devices' rely on vigilant monitoring of the onset of an unpredictable but potentially catastrophic event while it is happening. Lakoff points out that there is a dividing line in public health discourse between those experts and agencies who foreground the 'alarm' and dramatic risks of epidemics and those who believe in taking decisions based on rational calculation of statistics on actual risks, comparisons of the mortality caused by particular diseases: 'Coming from a certain segment of public health experts, we find the public display of numbers to make the case for rational decision on the basis of risk calculation, rather than based on alarm about potential (if uncertain) catastrophe' (Lakoff, in this issue). The study indicates the potentials in analysing contemporary health governance as ongoing responses to an 'indefinite series', not merely pertinent to sentinel devices for handling of epidemics, but also evident in, for example, preventive counselling, genetic predictions, calculus of health insurances in relation to probable life courses, and prenatal screenings.

\section{Medicalization, normalization, governmentalization}

A third dimension of Foucault's biopolitics gives emphasis to the permanent normalization and 'medicalization of society'. This dimension is more pertinent to liberal and social democratic regimes which, in Foucault's view, maintain an inherent impetus for an internal purification of the population. The danger in this context is not the dramatic violence of a totalitarian political regime but the much more mundane depoliticizing function of medical normalization which radiates from the power/knowledge nexus of modern health and social security systems (Foucault, 2003, p.252). Here, the problem of biopolitics is its tendency toward depoliticization, as politics becomes increasingly medical and statistical. Biopolitics as an increasing medicalization of society is, however, an ambiguous event in the history of human societies. If one foregrounds the significance of the Christian pastorate to biopolitics, including its injunction for continuous, life-long care and corrective guidance, a less reductive and more productive biopolitical imperative emerges. Taking this lineage of universal care which mutates into the political quest for optimization of life in the universal welfare state, it may be 
This paper has been accepted for publication in Economy \& Society, and the final (edited, revised and typeset) version of this paper will be published in Economy \& Society, Volume 43, by Taylor \& Francis, All rights reserved. (C) Taylor \& Francis Group

argued that the paradigmatic subject of biopolitics is not the homo sacer of the concentration camp but rather the Swedish middle-class social democrat (Ojakangas, 2005, p. 27), or rather that there is more than one such subject. In modern welfare states, the exercise of political sovereignty cedes space to the 'relative' disciplinary measures of calculating, comparing, and correcting.

This perceptual grid with its codes of normalization is rooted in modern medicine: 'Disciplines will define not a code of law but a code of normalization, and they will necessarily refer to a historical horizon that is not the edifice of law, but the field of the human sciences. And the jurisprudence of these disciplines will be that of clinical knowledge' (Foucault, 2003, p. 38). The problem of how regulation at the level of the population could be connected to disciplinary practices at the level of the individual and institutions is perhaps most vividly seen at the intersections of 'sexuality' and 'medicine' as intermediary registers that connect 'the two poles' of biopower - the regulation of the population and the disciplining of the individual body (Foucault, 1990, p. 146; Foucault, 2003, p 252). A general analytical asset in this version of biopolitics is the attention to such 'political intervention-techniques' (2003, p. 252) that spans and interlinks the individual body and the population.

Ayo Wahlberg and Nikolas Rose's article traces the emergence of such a register which connects the regulation of populations with the disciplining of individuals, by showing how a new style of epidemiological thinking emerged during the course of the 20th century which took morbid living, rather than morbid death, as its paramount problem. In this style of thinking, knowledge about the ways in which a disease impacted on the daily life of an individual would be aggregated to the level of national populations in an effort to calculate the burden of a particular disease. If in 'classic' epidemiology, the health of a population was linked to morbidity and mortality rates (i.e. the numbers of cases of and deaths from a particular disease) as a matter of life expectancy, in the 'adjusted' epidemiology of Disability Adjusted Life Years or Health Adjusted Life Expectancy, a population's 
This paper has been accepted for publication in Economy \& Society, and the final (edited, revised and typeset) version of this paper will be published in Economy \& Society, Volume 43, by Taylor \& Francis, All rights reserved. (C) Taylor \& Francis Group

health was to be gauged through a metrics of the severity or seriousness of a disease as a matter of burden. As they write, '[t]he problem is no longer merely one of finitude, of the extinction of life by death: the problem space now concerns the loss of the mode of life proper to vitality consequent on the impact of disease on the individual and collective. Accordingly, to assess the health of a population it is not sufficient to count the dead and record what they died from: we must study the "costs" of disease for "the living" - for each and for all - and how they individually and collectively suffer from, and cope with, the diseases with which they live' (Wahlberg and Rose, in this issue). Through such calculations, individual daily life has been broken down into domains of functional ability, discomfort, unease and relationality each of which can be measured, tabulated and eventually aggregated. As a consequence, they argue that morbid living - or living with disease - has come to be governmentalised. One of the byproducts of aggregation is normalization as populations come to be known in terms of averages, totals, rates and the like. Just as Canguilhem has shown how 'wherever there is life there are norms' (1994, p. 351), Wahlberg and Rose show how wherever there is living there are norms.

\section{Freedom, intervention and theological assumptions}

The fourth and last conceptual displacement of biopolitics happens in Foucault's 1979-lectures, The Birth of Biopolitics, where he presents biopolitics and liberal concerns about governing as intimately intertwined. In this context, Foucault suggests that 'only when we know what this governmental regime called liberalism was, will we be able to grasp what biopolitics is' (2008, p. 22). Foucault's claim that the 'specific problems of life and population' since the end of the eighteenth century have been 'constantly haunted by the question of liberalism' (2008, p. 324) suggests that it is simply not possible to analyse biopolitics without taking into account the liberal framework of governmental concerns within which the population-object emerged. An important insight following from this work to situate biopolitics and governmentality within a liberal rationality of government is the discovery of a permanent tension between biopolitical regulation and normalization, on the one hand, and the juridico- 
This paper has been accepted for publication in Economy \& Society, and the final (edited, revised and typeset) version of this paper will be published in Economy \& Society, Volume 43, by Taylor \& Francis, All rights reserved. (C) Taylor \& Francis Group

political emphasis on guaranteeing individual autonomy, on the other. While biopolitics has a potentially limitless impetus for regulation of the life of populations, in the broadest sense of the term, liberal governmental principles emphasise respect for legal subjects and free enterprise. It contains a sustained critique of excessive regulation and hence plays a moderating or keeping-in-check function in relation to aspirations of optimizing life. Mitchell Dean observes: '(T)he imperatives of bio-political norms that lead to the creation of a coordinated and centralized administration of life need to be weighed against the norms of economic processes and the norms derived from the democratization of sovereign subject of right' (Dean, 1999, p. 101).

Thus, in advanced liberal societies in which 'governing at a distance' has become the most pervasive form of power, issues of the self-limitation of governmental practice become urgent. That is, how to intervene to secure life without excessively interfering in the self-governing mechanisms of the domains of government. The problem becomes not one of 'modelling government on the rationality of the individual sovereign ... [but] on the rationality of those who are governed' (Foucault, 2008, p. 312). In this perspective, biopolitics is not ultimately about correcting individuals to match capacities predefined by expertise, since it has an openness towards the (perhaps unexpected) potentials inherent to the life of the governed (Nealon, 2008). Indeed, Nikolas Rose has shown the multiple ways in which subjects of liberal modes of reasoning are in fact obliged to be free, to become the architects and planners of their own lives (Rose, 1989; 1999). Thus, biopolitical regulation eschews a rigid binary scheme of exclusion/inclusion, since it is prepared to discover and operate upon diverse forms of life, including what are considered 'abnormal' personalities, traits and life styles. In this last version, biopolitics comes to encompass a more open-ended, reversible and multiplying set of governmental practices. Situating biopolitics within the framework of neoliberalism makes it possible to interrogate forms of subjectivation that do not rely upon rigid, disciplinary norms but rather operate through difference and diversified identities, such as, for instance, individual consumer profiles, particular sexual identities, and 
This paper has been accepted for publication in Economy \& Society, and the final (edited, revised and typeset) version of this paper will be published in Economy \& Society, Volume 43, by Taylor \& Francis, All rights reserved. (C) Taylor \& Francis Group

culturally differentiated health values. If the key problem of welfarist health policies was how to reduce patterned inequality in health by securing equal access to health services and implementing nationwide health programs, the population is now increasingly fragmented and differentiated into 'communities' of specific patient associations, interest groups, and insurance takers (Rose, 1996). The interconnections between such emphasis on differentiation into 'health communities', cultural diversity and the breaching of the expertise underpinning nation-wide health policy and neoliberal political rationalities constitute a significant contemporary research theme.

The idea of a new governmentality which works by allowing diversity and circulation to unfold is distinct for Foucault's formulations on political economy and neo-liberalism in his 1978 and 1979 lectures. In the 18th century, the political problem of ensuring the prince's right over a territory gave way to the problem of securing the vitality of the population. This transformation opened up the modern governmental problem, 'that is no longer that of fixing and demarcating the territory, but of allowing circulations to take place' (Foucault, 2007, p. 93). Instead of a sovereign command over a territory and legal subjects, there will be a management of transactions and circulations - a management directed at securing against the internal risks to these circulations. Foucault's analysis established a close association between this security rationality and the liberal discourse of laissez faire, or non-intervention (Munro, 2011, p. 3). Seen in conjunction with Foucault's observation that security works upon indefinite series, the idea of circulation conveys the idea of a governmentality that operates upon an open plane of transactions. This view resonates with the dictum adopted by later writers about 'governing through freedom' (Rose, 1999), and the suggestion that contemporary biopolitics is an expansive, limitless, and globalizing order (Hardt \& Negri, 2000). The core issue is whether biopolitics placed within the framework of liberalism is fundamentally about managing free circulations on a plane of immanent relations, or if sovereign control, scarcity and transcendent references remain inherent, unavoidable elements in liberal biopolitics. Each of the contributions in this special feature take up this 
This paper has been accepted for publication in Economy \& Society, and the final (edited, revised and typeset) version of this paper will be published in Economy \& Society, Volume 43, by Taylor \& Francis, All rights reserved. (C) Taylor \& Francis Group

tension between governing and allowing circulations to take place: Dean explores the bio-political dilemmas of excessive vital activity, Lakoff analyses the constant vigilance that epidemic outbreak monitoring requires, while Wahlberg and Rose show the tensions which emerged between measurements of the amount of death attributable to diseases and the ways in which these same diseases are seen to limit and impede the daily living of individuals.

Given that Foucault situates biopolitics within liberalism (or perhaps even equates it with neoliberalism), no wonder he pays such heed to a genealogy of liberalism. It has been common to view the emerging liberal political economy in the $18^{\text {th }}$ century as an atheistic discipline which would depart from the theological underpinnings of previous state reason. But key liberal thinkers who inform Foucault's account like Adam Smith and Adam Ferguson (Foucault, 2008, p. 282; Dean, 2013, p. 91) display important theological dimensions that bear on the genealogy. Foucault's analysis of Smith and Ferguson emphasizes modern governmental themes about spontaneous, self-generating order, the necessary self-limitation of government and the undirected, unintentional nature of human progress.

Other scholars have argued that Smith and Ferguson's thought retains a significant theological element, insofar as they assert a divine presence in occasional events, a 'providential order' independent of human will that leads humanity towards higher ends. Hence, Lisa Hill emphasizes that Ferguson, as a moral philosopher, sought to 'persuade a sophisticated, enlightenment readership of the enduring relevance of the agency of the "Divine Architect" to modern social theory' (Hill, 1998, p. 58). Ferguson's unique synthesis of classical teleology with a modern conception of progress makes possible his dual claim of self-creation of the human species and the existence of a providential order. This claim is predicated upon a distinction between 'effective causes' and 'final causes' which was common to early Enlightenment thought. The first refer to the level of lower ends, where individuals carry out seemingly random actions to achieve immediate goals, whereas the latter designates the realization of 
This paper has been accepted for publication in Economy \& Society, and the final (edited, revised and typeset) version of this paper will be published in Economy \& Society, Volume 43, by Taylor \& Francis, All rights reserved. (C) Taylor \& Francis Group

order, happiness and progress at the overall social level (Hill, 1998, p. 52). Here Ferguson invokes an idea of efficient causes delegated to individual human agents which resonates with Adam Smith's notion of 'the invisible hand'. Dean argues, however, that it is a mistake to view the invisible hand as the accumulated result of self-interested action without God or any divine providence (Dean, 2013, p. 84). Hill as well, in her scholarship on Ferguson and Smith (2001), argues that they meet the 'minimal requirement of teleology' insofar as 'any teleological formulation must, by definition, refer to God as unrealized perfection' (1998, p. 54).

The theological dimension in early liberal economic thought has significant consequences for how the mechanisms inherent in a living population can be conceptualised and governed. For one thing, this may complicate the assumption that liberal political economy is best and principally conceived as a secular break which allows infinite transactions to flow across an open space. In the case of a contemporary liberal thinker, Thomas Malthus, who theorised the reproductive mechanisms of the population, we find the contrary thesis about scarce resources within a confined space. Like Ferguson and Smith, Malthus' thought bears the influence of theology in his key assertion that God-given principles in nature through which mind is produced from matter, an awakening by 'the animating touches of divinity' (Malthus quoted in Dean, 1991, p 88). Dean traces the re-emergence of the Malthusian doctrine in diverse streams of thought related to issues of poverty and assistance, environmental threats, and international security (Dean, in this issue). Notably, for instance, the quasi-theological Malthusian assumption of a permanent imbalance between human fertility and the means of sustenance reappears in considerations of North American concerns over national security in respect of the containment of the Soviet Union and 'revolutionary pathologies' springing from the population crises in developing countries. Dean also utilizes his examination of Malthusianism for a critical dialogue with Foucault. He argues that rather than Foucault's claim for a major rupture in the art of government between the sovereign rule over a territory to securing the productive forces of the living population unfolding in open series, we have a 
This paper has been accepted for publication in Economy \& Society, and the final (edited, revised and typeset) version of this paper will be published in Economy \& Society, Volume 43, by Taylor \& Francis, All rights reserved. (C) Taylor \& Francis Group

constraining triad of human fertility, scarce resources and confined space. The Malthus effect holds a critical potential to interrogate contemporary liberal doctrines of social order and appropriate state policy, particularly in light of the question whether modern biopolitics of the population can fundamentally do without theological and metaphysical assumptions (Babik, 2012).

\section{The government of life today}

Clearly, much has happened since the Europe of Foucault's initial analyses of bio-politics and governmentality, yet the concepts remain analytically potent, especially when mobilised in tandem to help investigate problematics of human life. The articles in this special feature point to a series of transformations that have played out over the course of the $20^{\text {th }}$ century and into the $21^{\text {st }}$. The government of life, we suggest, remains a core political problematic, whether at the level of populations, bodies, organs, cells or molecules.

Let us point to three thematics that emerge out of this collective set of contributions which constitute pertinent avenues for future empirical and conceptual attention. Firstly, ever since Limits to Growth (Meadows; Meadows; Randers, and Behrens, 1972) and Limits to Medicine (Illich, 1975) were published in the early 1970s, vital finitude on a global level has become a decisive rationale for governmental intervention. This finitude can be discerned in the genopolitics of the reproductive capacity of human populations and the human species - the Malthus Effect - that is currently playing out in areas such as welfare reform, immigration policy, sustainability, global public health and environmental movements. A living population is subject to inherent limits, limits which are exposed through excessive vital activity which ironically ends up threatening the very vitality it seeks to strengthen. In this current 'age of anthropocene', future studies of the government of life will do well to examine the ways in which such limits are mobilised for political ends, whether these pertain reigning in 
This paper has been accepted for publication in Economy \& Society, and the final (edited, revised and typeset) version of this paper will be published in Economy \& Society, Volume 43, by Taylor \& Francis, All rights reserved. (C) Taylor \& Francis Group

the excesses of economic growth, encouraging sustainable consumption, improving unhealthy lifestyles, promoting family planning or protecting the environment.

Secondly, the ways in which the population - as a multiplicity of men - is monitored, measured and thereby rendered calculable, comprise an important arena for further scrutiny. Even if the bio-political figure of the population remains a privileged object of knowledge and management today, novel forms of calculation, vigilance and measurement are constantly unfolding, changing the ways in which governmental interventions are configured and priorities negotiated. Living populations are dynamic, and if we approach them as spatial-temporal zones of open series of probabilities, then we must attend to the techniques of calculation and styles of reasoning which inform and organise interventions which aim to redress vital problems.

Finally, as social scientists we must continue to trace and follow processes of governmentalisation as these unfold in different arenas, providing grids of perception and prescription and spawning novel forms of normalisation and governing. In Foucault's analyses of $15^{\text {th }}$ and $16^{\text {th }}$ century Europe, it was the administrative state that gradually came to be 'governmentalized'. In the succeeding centuries, we have seen how such processes of governmentalisation would come to organise not just state administrations but a broad range of institutions and organisations which were somehow engaged in the "conduct of the conduct'. While much empirical attention has been directed at the governmentalisation of molecular life - or life itself - in recent years, what we learn from the articles that follow is that the governmentalisation of living (as a social, economic or cultural activity) deserves equal attention if we are to come to grips with the government of life today.

To approach these three (and many other) empirical thematics, we have proposed a series of conceptual frames for understanding the management of populations and biopolitical problems in terms of the 
This paper has been accepted for publication in Economy \& Society, and the final (edited, revised and typeset) version of this paper will be published in Economy \& Society, Volume 43, by Taylor \& Francis, All rights reserved. (C) Taylor \& Francis Group

government of life. First, there is the need to interrogate the changing conditions of possibility for resurrections of sovereign power over life, including state-racism and recent police and military interventions carried out in the name of national security. Second, there is a remaining potential in exploring the productive co-existence, the intertwinings, and discordances of divergent rationalities for governing life - perhaps demarcating new 'prototypes' alongside law, discipline and security. Third, characterising modern biopolitics as working upon 'infinite series' offers a helpful perspective for analysing current developments in sentinel devices, insurantial techniques, health predictions based on 'big data' and more. Fourth, the discovery of sustained theological foundations and the category of scarcity and limits can be further utilised in critically interrogating contemporary forms of neoliberal governance of issues of the population. And fifth, and finally, ongoing processes of governmentalization in terms of the production of new categories of knowledge and intervention on a global scale call for vigilant empirical and analytical work. For scholars inspired by Foucault this work crucially involves deliberating the ways in which his original concepts and insights can be developed for the present context and our present urgent concerns. The articles collected in this special feature begin this task.

\section{References:}

Agamben, G. (1998). Homo Sacer: Sovereign Power and Bare Life. Stanford, Calif.: Stanford University Press.

Agamben, G. (2011). The Kingdom and the Glory: For a Theological Genealogy of Economy and Government. Stanford, CA: Stanford University Press.

Babik, M. (2012). 'Beyond Totalitarianism: (Re)Introducing Secularization Theory to Liberal Narratives of Progress', Politics, Religion \& Ideology, 13, 289-309. 
This paper has been accepted for publication in Economy \& Society, and the final (edited, revised and typeset) version of this paper will be published in Economy \& Society, Volume 43, by Taylor \& Francis, All rights reserved. (C) Taylor \& Francis Group

Badiou, A. (2007). The Century. Cambridge: Polity Press

Barry, A.; Osborne, D. and Rose, N. (1996). Foucault and Political Reason. London: UCL Press.

Bröckling, U., Krasmann, S. \& Lemke, T. (2010). Governmentality: Current Issues and Future Challenges. London: Routledge.

Bussolini, J. (2010). 'Review essay: critical encounter between Giorgio Agamben and Michel Foucault, Foucault Studies, 10, 108-143.

Canguilhem G. (1994). A Vital Rationalist: Selected Writings from Georges Canguilhem. New York: Zone Books.

Collier, S. (2009). 'Topologies of Power: Foucault's Analysis of Political Government beyond 'Governmentality', Theory Culture Society, 6, 78-108.

Dean, M. (1991). The Constitution of Poverty: Toward a Genealogy of Liberal Governance. London: Routledge.

Dean, M. (1999). Governmentality: Power and Rule in Modern Society. London: Sage.

Dean, M. (2002). 'Powers of life and death beyond governmentality', Cultural Values 6, 119-138.

Dean, M. (2012). 'Governmentality meets theology: “the king reigns, but he does not govern”', Theory, Culture and Society 29, 145-158. 
This paper has been accepted for publication in Economy \& Society, and the final (edited, revised and typeset) version of this paper will be published in Economy \& Society, Volume 43, by Taylor \& Francis, All rights reserved. (C) Taylor \& Francis Group

Dean, M. (2013). The Signature of Power: Sovereignty, Governmentality and Biopolitics. London: Sage.

Esposito, R. (2008). Bios: Biopolitics and Philosophy. Minneapolis: University of Minnesota Press.

Foucault, M. (1982). The Subject and Power. In H. Dreyfus \& P. Rabinow: Michel Foucault:

Beyond Structuralism and Hermeneutics. Chicago: University of Chicago Press.

Foucault M. (1990). The History of Sexuality Vol. 1: An Introduction. New York: Vintage Books.

Foucault, M. (2003). Society Must Be Defended: Lectures at the Collège de France, 1975-76. New York: Picador.

Foucault, M. (2007). Security, Territory, Population: Lectures at the Collège de France 1977-1978.

New York: Palgrave Macmillan.

Foucault, M. (2008). The Birth of Biopolitics: Lectures at the Collège de France 1978-1979. New York: Palgrave Macmillan.

Franklin, S. (2000). Life Itself: Global Nature and the Genetic Imaginary. in Franklin, S., Lury, C. and Stacey, J. Global Nature, Global Culture. London: Sage. pp. 188-227.

Franklin, S. (2007). Dolly Mixtures: The Remaking of Genealogy. Durham: Duke University Press

Greco, M. (1993). Psychosomatic subjects and the 'duty to be well': Personal agency within. Economy and Society, 22, 357-372. 
This paper has been accepted for publication in Economy \& Society, and the final (edited, revised and typeset) version of this paper will be published in Economy \& Society, Volume 43, by Taylor \& Francis, All rights reserved. (C) Taylor \& Francis Group

Greco, M. (2009). Thinking beyond Polemics: Approaching the Health Society through Foucault. Österreichische Zeitschrift für Soziologie, 34, 13-27.

Hardt, M. \& Negri, A. (2000). Empire. Cambridge, Mass.: Harvard University Press.

Hill, L. (1998). The invisible hand of Adam Ferguson. The European Legacy, 3, 42-64.

Hill, L. (2001). The Hidden Theology of Adam Smith, European Journal of Economic Thought, 1, 1-29.

Illich, I. (1975). Limits to Medicine: Medical Nemesis, the Expropriation of Health. Calder \& Boyars

Lakoff, A. and Collier, S. (2008). Biosecurity Interventions: Global Health and Security in Question.

New York: Columbia University Press.

Larsen, L. T. (2010). Framing knowledge and innocent victims. Europe bans smoking in public places.

Critical Discourse Studies, 7, 1-17.

Meadows, D.H., Meadows, D.L., Randers, J. and Behrens, W.W. (1972). Limits to Growth. New York: New American Library.

Munro, I. (2012). The Management of Circulations: Biopolitical Variations after Foucault. International Journal of Management Reviews, 14, 345-362. 
This paper has been accepted for publication in Economy \& Society, and the final (edited, revised and typeset) version of this paper will be published in Economy \& Society, Volume 43, by Taylor \& Francis, All rights reserved. (C) Taylor \& Francis Group

Nealon, J.T. (2008). Foucault Beyond Foucault: Power and its Intensifications since 1984, Stanford University Press.

Ojakangas, M. (2005). Impossible Dialogue on Bio-power Agamben and Foucault. Foucault Studies, 2, $5-28$.

Pii, K.H. and Villadsen, K (2013). Protect the Patient from Whom?: When Patients Contest Governmentality and Seek More Expert Guidance. Social Theory \& Health, 1, 19-39.

Rabinow, P. (1996). Making PCR. A Story of Biotechnology. Chicago: University of Chicago Press.

Rabinow, P. \& Rose, N. (2006). Biopower Today. Biosocieties, 1, 195-217.

Rajan, K. S. (2006). Biocapital: The Constitution of Postgenomic Life. Durham: Duke University Press.

Rose, N. and Abi-Rached, J. (2013). Neuro: The New Brain Sciences and the Management of the Mind. Princeton, New J.: Princeton University Press.

Rose, N. (1996). The Death of the Social? Refiguring the territory of government. Economy and Society, $25,3,327-56$

Rose, N. (1989). Governing the Soul: the Shaping of the Private Self. London: Routledge

Rose, N. (1999). Powers of Freedom: Reframing Political Thought. Cambridge: Cambridge University Press. 
This paper has been accepted for publication in Economy \& Society, and the final (edited, revised and typeset) version of this paper will be published in Economy \& Society, Volume 43, by Taylor \& Francis, All rights reserved. (C) Taylor \& Francis Group

Rose, N. (2007). The Politics of Life Itself: Biomedicine, Power, and Subjectivity in the Twenty-First Century. Princeton, New J.: Princeton University Press.

Rose, N. and Miller, P. (1992). Political Power beyond the State: Problematics of Government. The British Journal of Sociology, 2, 173-205.

Valverde, M. (1997). Slavery from Within: The Invention of Alcoholism and the Question of Free Will. Social History, 22, 251-268.

Villadsen, K. and Karlsen, M.P. (2012). Public Policy and Foucaultian Critique: Towards a happy marriage?, Review of European Studies, 4, 138-147.

Žižek, S. (2004). From Politics to Biopolitics ... and Back. The South Atlantic Quarterly, 103, 501-521.

Wahlberg, A. (2006). Bio-politics and the promotion of traditional herbal medicine in Vietnam. Health: An Interdisciplinary Journal for the Social Study of Health, Illness and Medicine, 10, 123-147.

Wahlberg, A. (2007). Measuring progress: Calculating the life of nations. Distinktion: Scandinavian Journal of Social Theory, 14, 65-82.

Weir, L. (2006). Pregnancy, Risk and Biopolitics: On the Threshold of the Living. Economy and Society, 27, 249-258. 